\title{
$\mathfrak{u} \mathfrak{e} \mathfrak{b} \mathfrak{u} \mathfrak{h} \mathfrak{e} \mathfrak{n}$
}

jux

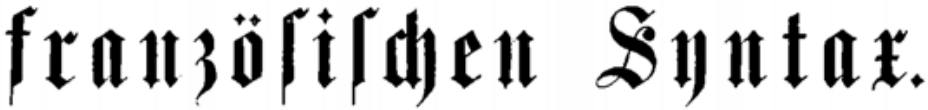

Bon

\section{Eoutard Gerfá,}

Ebertebrer an ber böberen (Metvetbeídjule zи 2Ragbeburg.

\section{Reipzig.}

Serlag von Beit \& Eomp.

1876. 
